\title{
MITIGATION OF URBAN HEAT ISLAND EFFECT THROUGH DESIGN
}

\author{
Rishika Sood $^{1 *}$, Dr. Anjali S. Patil ${ }^{2}$ \\ ${ }^{1}$ B.Arch, Department of Architecture and Planning, MITS, Gwalior, India, rishika699@gmail.com \\ ${ }^{2}$ Head and Associate Professor, Department of Architecture and Planning, MITS, Gwalior, India, \\ anjalipatil@mitsgwalior.in \\ ${ }^{*}$ Corresponding author
}

\begin{abstract}
Today almost fifty five percent of the world's population lives in cities. It is estimated that by 2050 , the population would grow by 2.5 billion with about sixty eight percent of the world's population would be living in cities. Along with this population projection, it has also been estimated that the phenomenon of climate change will increase abundantly in this century and will lead to climate related extreme events. To combat such events in urban areas, their causes and consequences should be understood; to mitigate them and minimize the negative impacts of urbanization.

Modification of land surfaces and uses in urban areas has proved to have drastic impacts on local climates. The net effect of central business districts, commercial areas and dense housing that replace natural land covers in urban areas greatly alter the exchange of energy and moisture between the surface and atmosphere; thereby modifying surface microclimate variables such as temperature and humidity (Menglin Jin, 2005).This often leads to the phenomenon of Urban Heat Island Effect in cities, whereby urbanized areas are characterized to have temperatures higher than those of their surrounding rural areas. Such elevations in temperature lead to substantial increase in thermal discomfort and air pollution, leading to deterioration of living environment and severe consequences on human health and well-being. It is estimated that about three billion people living in urban areas around the globe grieve to the problems caused by Urban Heat Island Effect (RIZWAN Ahmed Memon, 2007).
\end{abstract}

Although Urban Heat Island Effect is not a direct consequence of global climate change and varies regionally at microclimate levels; it contributes to increased energy demands, straining air conditioning systems and contributing to global warming. The phenomenon is also expected to exacerbate due to the rising temperatures predicted in the framework of climate change scenario for the coming decades. To ensure a livable environment in cities, it is therefore of crucial importance to create sustainable built environments that are sensitive to this phenomenon.

In this research, the Urban Heat Island Effect, its generation and impacts have been studied in detail using literature reviews. After a clear understanding of Urban Heat Island Effect has been established, design strategies for its mitigation have also been studied at Microscale levels from literature reviews. Along with their implementation, the potential reduction in temperatures resulting from these strategies have been analyzed. Post this study, a site has been chosen and a hypothetical-built environment has been created on the site where the design strategies have been tested through simulations. Envi Met software has been used for the simulations and the basic weather data for the site has been taken from secondary sources. The output from the simulations has been compared to the data obtained in the literature reviews to formulate 
appropriate inferences. As the output from the simulations was based on basic weather data of the region, it has only been used for a comparative analysis and was not accounted to be $100 \%$ accurate. Additionally, while the Urban Heat Island Effect is a vast phenomenon in urban areas, the design strategies for its mitigation in this research have been limited only to buildings and their immediate outdoor environment.

Keywords: Urban Heat Island Effect, Sustainable Design, Simulation Software, Urban Microclimate

\section{INTRODUCTION}

The surface of the earth has experienced various changes because of anthropogenic activities over the past half century, mostly because of deforestation and urbanization. Urbanization involves concentration of population and loss of natural surfaces for the construction of built environments to accommodate this population.

The plants in natural vegetative areas absorb water from the ground and then store it in their stems and leaves. This water is eventually released into the air by the process of transpiration. This mechanism helps the plants to cool themselves as well as their surrounding environment. In urban areas, most of the plantations and natural green covers are replaced by roads, sidewalks, parking lots and buildings. The absence of vegetation in these urban areas substantially limits transpiration which eventually reduces natural cooling of the surrounding environment. Urban building materials such as cement, asphalt, brick, glass and steel absorb and store more heat which is reflected back into the surroundings, leading to elevated temperatures. Unlike natural surfaces, the impermeable nature of these materials does not allow water to pass through them and eventually seep into the soil. Without a cycle of flowing and evaporating water, these surfaces have nothing to cool them down.

When this heat generated by urban surfaces and materials is combined by anthropogenic heat released in urban areas because of overpopulation and pollution; it leads to a considerable increase in temperatures and the creation of Urban Heat Islands.

\subsection{Aim}

To study effective design strategies for mitigation of the Urban Heat Island Effect at micro scale levels and tests their feasibility through Simulation Software.

\subsection{Objectives}

This research study was undertaken with the following major objectives:

- To understand the causes and impacts of the Urban Heat Island Effect in cities.

- To study the existing mitigation design strategies for Urban Heat Island Effect and their application at microscale levels.

- To implement these design strategies on a built-up area using simulation software.

- To analyze the effect of these design strategies in reducing the Urban Heat Island Effect in the existing area through the output obtained from the simulations.

\section{URBAN HEAT ISLAND EFFECT}

The Urban Heat Island Effect can be described as a phenomenon which occurs when temperature of the urban area is hotter than its rural surroundings, dependent upon local climatic conditions caused by the urban area surface characteristics and heat released by anthropogenic activities.

\subsection{Generation of Urban Heat Island Effect in Cities}

The heat generated and contained in an area comes from the sun in the form of solar radiations and from power plants, automobiles, air-conditioners and other sources as anthropogenic heat. Almost all anthropogenic heat enters into the environment instantly and directly. On the other hand, only part of solar radiations heats up the environment directly, the rest are absorbed by the complicated urban built structures 
and heat up the environment indirectly. The basic heat transfer and energy conservation processes, such as conduction, convection and radiation play their characteristic roles in this heat exchange (RIZWAN Ahmed Memon, 2007).

The structures on the ground level such as gardens, green and paved areas along with the roof surfaces that are exposed to the solar radiations, absorb it to different extend. These radiations are continuously absorbed and stored in the form of heat energy during the day light hour. However, when this heat is released to the environment, the amount of heat released may depend upon several factors such as the design of buildings, albedo of materials used on the outer surfaces of buildings, vegetation and city population.

\section{DESIGN STRATEGIES ADOPTED FOR ITS MITIGATION}

The urban heat island effect has recently emerged as an environmental issue for consideration, separate from climate change. Scientists and climatologists have carried out their part; the effect has been discovered, researched, established and understood. The next step is mitigation, and this is where design has a role to play. The issues of environment and sustainability are nothing new to architecture, but the urban heat island raises a new, unique set of considerations that need to be addressed at both microscale and mesoscale levels.

Throughout history, Architects and designers have conducted several researchers to study the internal environment of a building and the passive design strategies that maybe devised to reduce internal temperatures for occupant comfort. However, to mitigate this phenomenon; it is extremely important to consider how the external building surfaces and urban environment behaves. Much like the natural environment, the urban environment is also very diverse and needs to be designed with consideration. Based on the characterises of the UHI, several design strategies have been devised by designers to reduce its negative impacts. These include:

\subsection{Roofs}

The role of roofs in mitigating the UHI effect is very critical as these are exposed to large amounts of solar radiations throughout the day. Over the years, many researchers have studied the impact of roof surfaces and come to the conclusion that these are a major factor in the thermal balance of a city. In their research paper "Global Cooling: Policies to Cool the World and Offset Global Warming from CO2 Using Reflective Roofs and Pavements", the authors mentions that roofs account for $25 \%$ of the city's surface areas and therefore the heat absorbed and released by roofs has a notable impact on the city's temperature (Akbari \& Levinson, 2009). This fraction of Roof area may also vary in different regions from $20 \%$ for less dense cities to $25 \%$ for more dense cities.

\subsubsection{Green roofs}

Green Roofs are a typically a vegetative layer on the roof with a growing medium like soil over a waterproofing membrane (Yang Junjing, 2018). Green roofs are used globally for the insulation of buildings (Erica Oberndorfer, 2007), as they enhance heat transfer through roofs and provide steadier outside roof temperature in cold winters and hot summers. While green roofs in the form of roof gardens have ancient roots, in the contemporary era these are of two types, mainly the extensive and intensive green roofs.

Also categorised as roof gardens, Intensive roofs are used on commercial buildings and consist of large green areas with a variety of plants, including grass, plant shrubs and trees; paths and walkways; and furniture elements such as benches, tables, greenhouses, ponds and fountains. Such roofs require very high maintenance and heavy construction for support as it includes a deep growing medium and varied plant grouping (Yang J, 2014.). Extensive roofs on the other hand are majorly used for residential buildings, but can also be used for outbuildings like shades and garages. These are built strictly for functional purposes and are not suited to walk upon. They are cost effective, easy to maintain, give high thermal advantage and high-water performance, while keeping the overall weight of the roof low. 
Table 1: Case Studies for Green Roofs

\begin{tabular}{|l|l|l|}
\hline $\begin{array}{l}\text { Research (Case } \\
\text { Studies) }\end{array}$ & Findings & Inferences \\
\hline $\begin{array}{l}\text { (YOSHINOBU } \\
\text { HARAZONO, } \\
1990)\end{array}$ & $\begin{array}{l}\text { A system for growing plants on rooftops was set up on a } \\
\text { building at the University of Osaka on which } 43 \text { types of plants, } \\
\text { trees and bushes were set up. The air temperature in the room } \\
\text { beneath the vegetation was kept lower than that beneath the } \\
\text { control by } 2^{\circ} \mathrm{C} .\end{array}$ & $\begin{array}{l}\text { Green Roofs can effectively } \\
\text { reduce indoor air } \\
\text { temperatures of the } \\
\text { buildings they are planted } \\
\text { on. }\end{array}$ \\
\hline $\begin{array}{l}\text { (Jaekyoung Kim, } \\
2020)\end{array}$ & $\begin{array}{l}\text { The study conducted on Seoul National University's campus } \\
\text { via an ENVI-Met analysis simulation concluded that a } \\
\text { temperature reduction of was } 0.3 \circ \mathrm{C} \text { was observed for a fully } \\
\text { afforested (extensive roof) while a temperature difference of } \\
0.2 \circ \mathrm{C} \text { was observed for intensive roof gardens. }\end{array}$ & $\begin{array}{l}\text { Extensive roofs have } \\
\text { cooling capacities than } \\
\text { intensive roofs. }\end{array}$ \\
\hline
\end{tabular}

\subsubsection{Pavements}

As Pavements cover nearly 30-45\% of land cover in a typical city (Akbari H, 1999) (Rose, 2003), they are an important urban element to consider for Urban Heat Island Effect Mitigation. The long-wave emission from the pavement during the night is obstructed by the adjacent building walls, hence retaining the heat absorbed in the pavement. The inadequate heat drainage from the pavement surfaces also leads to warmer near-surface air temperatures (Golnoosh Manteghi, 2020). Additionally, conventional paving materials can reach peak summertime temperatures of $48.67{ }^{\circ} \mathrm{C}$ transferring excessive heat to the air above them and heating stormwater as it runs off the pavements into local waterways (Agency, Using Cool Pavements to Reduce Heat Islands, 2020).

Over the years, several researches have been conducted to design pavements efficient in reducing the Urban Heat Island Effect. These studies have concluded that the best parameters of mitigating the phenomenon are surface reflectivity and porosity (Golnoosh Manteghi, 2020). While the reflectivity reduces the amount of heat absorbed by the pavements, the voids in porous pavements facilitate the evaporation of infiltrated water thus resulting in a cooling effect (Haselbach, 2009).This has led to the design of Cool Pavements in the recent decades. Cool Pavements refer to paving materials that reflect more solar energy, enhance water evaporation or have been otherwise modified to remain cooler than conventional pavements (Agency, Using Cool Pavements to Reduce Heat Islands, 2020).

Table 2: Case Studies for Pavements

\begin{tabular}{|l|l|l|}
\hline $\begin{array}{l}\text { Research (Case } \\
\text { Study) }\end{array}$ & Findings & Inferences \\
\hline $\begin{array}{l}\text { K E. E. } \\
2018)\end{array}$ & $\begin{array}{l}\text { A large-scale implementation of cool asphaltic and concrete } \\
\text { pavements in a major traffic axis of Western Athens, covering } \\
\text { a total zone of } 37,000 \mathrm{~m} 2 \text { was done and it was found that } \\
\text { cool reflective pavements demonstrated lower surface } \\
\text { temperatures compared to the conventional ones and the } \\
\text { amount of reduction reached } 7.5 \cdot \mathrm{C}-6.1 \cdot \mathrm{C} \text { in summers. }\end{array}$ & $\begin{array}{l}\text { Reflective pavements can } \\
\text { result in reduction in surface } \\
\text { temperatures which can further } \\
\text { cause the cooling of } \\
\text { stormwater. }\end{array}$ \\
\hline (Yong Liu, 2018) & $\begin{array}{l}\text { Evaporation-enhancing permeable pavement could contribute } \\
\text { substantially to UHI mitigation, and was a maximum } 9.4^{\circ} \mathrm{C} \\
\text { cooler than conventional permeable pavement }\end{array}$ & $\begin{array}{l}\text { Permeable Pavements can } \\
\text { contribute to UHI mitigation by } \\
\text { Iowering temperatures. }\end{array}$ \\
\hline
\end{tabular}

\subsubsection{Green Walls}

In addition to roofs, walls of buildings are also exposed to solar radiations throughout the day. In the recent decades, studies have shown that walls, having a greater area than roofs, if positioned in a way that had greater exposure to the sun, could be said to contribute more to urban heating than their more vastly studied rooftop counterpart (Arnfield, 2003).

Green walls are vegetative vertical surfaces covered with plants that are either rooted on the ground, wall surface or in modular panels that are attached to the façade. These can be used as passive energy saving 
systems through four mechanisms: the interception of solar radiation as a consequence of the shadow produced by the vegetation, the insulation that the vegetation produces when attached to a building wall, blocking the hot wind on the facade, and the evaporative cooling effect that occurs by evapotranspiration of the plants (Pérez, 2011).

Table 3: Case Studies for Green Walls

\begin{tabular}{|l|l|l|}
\hline $\begin{array}{l}\text { Research } \\
\text { (Case Study) }\end{array}$ & Findings & Inferences \\
\hline $\begin{array}{l}\text { (Alexandri E, } \\
2008)\end{array}$ & $\begin{array}{l}\text { There is an important potential of lowering urban } \\
\text { temperatures when the building envelope is covered with } \\
\text { vegetation }\end{array}$ & $\begin{array}{l}\text { Green walls can reduce } \\
\text { temperatures in Urban Areas. }\end{array}$ \\
\hline $\begin{array}{l}\text { (U Mazzali, } \\
2013)\end{array}$ & $\begin{array}{l}\text { During sunny days external surface temperature differences } \\
\text { between the bare wall and the covered wall from a minimum } \\
\text { of } 12^{\circ} \mathrm{C} \text { to a maximum of } 20^{\circ} \mathrm{C} \text { were recorded }\end{array}$ & $\begin{array}{l}\text { Green walls can significantly } \\
\text { reduce temperatures when } \\
\text { compared to conventional bare } \\
\text { walls. }\end{array}$ \\
\hline
\end{tabular}

\subsubsection{Urban Forestry}

Urban forests can be defined as groups of trees or individual trees located in urban and peri-urban areas; they include, therefore, forests, street trees, trees in parks and gardens, and trees in derelict corners. Urban forestry helps to maintain the tree resources in an urban area and results in several economic, environmental and sociocultural benefits. The use of trees to mitigate Urban Heat Island effect is a valuable resource. Open green spaces, tree canopy, green roofs and vertical greening screens all provided some benefit in reducing temperatures in urban areas, but overhead vegetation, mainly tree canopies provide one of the best options for reducing urban temperatures (Briony A.Nortona, 2015).

Table 4: Case Studies for Urban Forestry

\begin{tabular}{|l|l|l|}
\hline $\begin{array}{l}\text { Research } \\
\text { (Case Study) }\end{array}$ & Findings & Inferences \\
\hline $\begin{array}{l}\text { (T Elmqvist, } \\
2015)\end{array}$ & $\begin{array}{l}\text { A } 10 \% \text { increase in tree cover in urban areas can create a } \\
\text { reduction of } 3-4^{\circ} \mathrm{C} \text { in ambient air temperatures. This decrease } \\
\text { in temperature then reduced the energy usage from air } \\
\text { conditioning, which further reduced consumption of fossil fuels } \\
\text { and improves air quality in cities }\end{array}$ & $\begin{array}{l}\text { The air temperature reductions } \\
\text { by trees help to mitigate Urban } \\
\text { Heat Island Effect and result in } \\
\text { energy savings. }\end{array}$ \\
\hline $\begin{array}{l}\text { Wang Y, } \\
2016)\end{array}$ & $\begin{array}{l}\text { Road side tree planting could provide Urban Heat Island } \\
\text { mitigation to create better pedestrian thermal environment, } \\
\text { and also reduce temperature in the city centre areas. }\end{array}$ & $\begin{array}{l}\text { Road side tree plantations can } \\
\text { reduce temperatures on roads. }\end{array}$ \\
\hline
\end{tabular}

\section{SIMUALTIONS FOR DESIGN STRATEGIES}

ENVI-met is a computer program to simulate the outdoor microclimate in urban environment. For the purpose of simulating temperatures in the outdoor microclimate to calculate the Urban Heat Island Effect, ENVI met is an excellent option and therefore has been used in the research.

\subsection{Methodology}

The site chosen for the simulations is of Taleigão, near Panaji, the capital city of Goa. The metrological data for the site was collected through secondary sources. Based upon the design strategies studied in the literature review, a built environment consisting of a neighbourhood with two storeyed bungalows, surrounded with open areas and roads was designed on the chosen site. A 3-Dimensional model of the site was then constructed. For the first set of simulations, the 3-Dimensional model i.e., Model 1 was assigned conventional design strategies and 2-Dimensional potential air temperature graphs for the model were obtained. In the second set of simulations, in the same 3-Dimensional model was named Model 2 and assigned the design strategies studied to mitigate the Urban Heat Island Effect to take out the potential air temperature graphs. The graphs obtained from the both the models i.e., Model 1 and Model 2 were then compared to each other to understand the temperature reductions, if any by the use of sustainable design. 


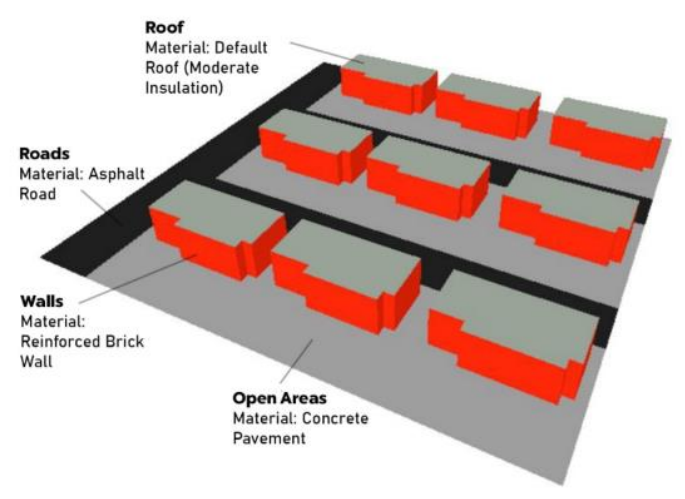

Figure 1: Model 1 with conventional design

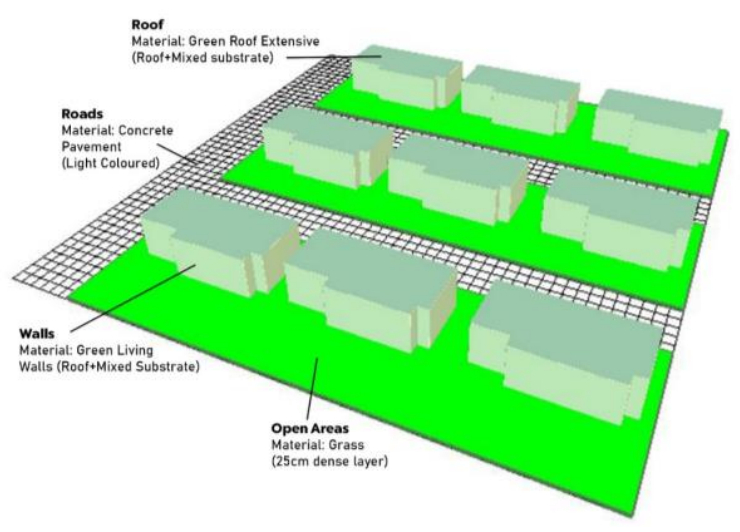

Figure 2: Model 2 with sustainable design

\subsection{Input Data for Simulations}

The following input parameters were fed into the model and the simulations were run for a time period of 10 hours (7am-5pm) on $25^{\text {th }}$ April 2021.

Table 5: Input Data for Simulation. Source: En Climate, Wind Finder and Weather Statics

\begin{tabular}{|l|l|l|}
\hline Parameter & Model 1 & Model 2 \\
\hline Simulation Date and Time & 25 April 2021, 7am-5pm & 25 April 2021, 7am-5pm \\
\hline Simulation interval and duration & 1 hour and 10 hours in total & 1 hour and 10 hours in total \\
\hline Wind Speed and Direction & $5 \mathrm{~km} / \mathrm{h}$ and West & $5 \mathrm{~km} / \mathrm{h}$ and West \\
\hline $\begin{array}{l}\text { Minimum and Maximum } \\
\text { values }\end{array}$ & $24^{\circ} \mathrm{C}$ and $34^{\circ} \mathrm{C}$ & $24^{\circ} \mathrm{C}$ and $34^{\circ} \mathrm{C}$ \\
\hline
\end{tabular}

\subsection{Results}

The simulation results were obtained in the form of hourly potential air temperature graphs. As the simulations were run for 10 hours, 10 graphs were obtained for each model individually.

\subsubsection{Potential Air Temperature graphs}

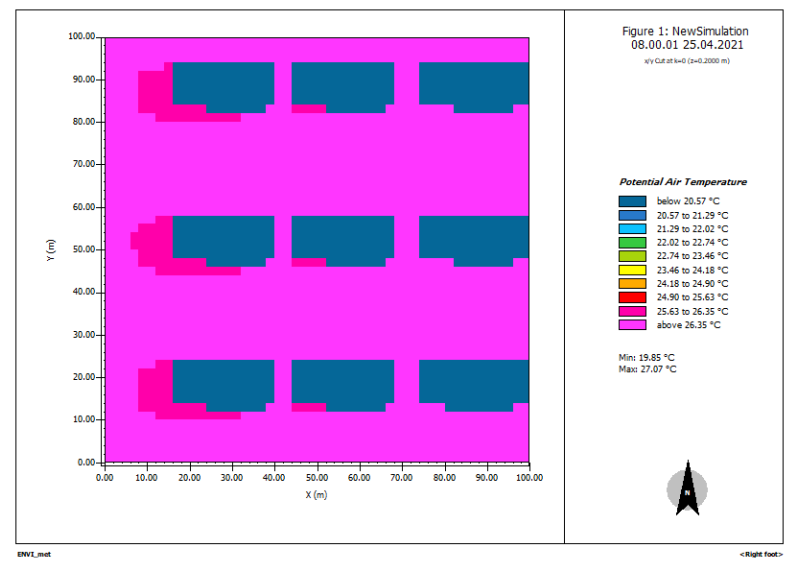

Figure 3: Graph for Model 1 (8AM-9 AM)

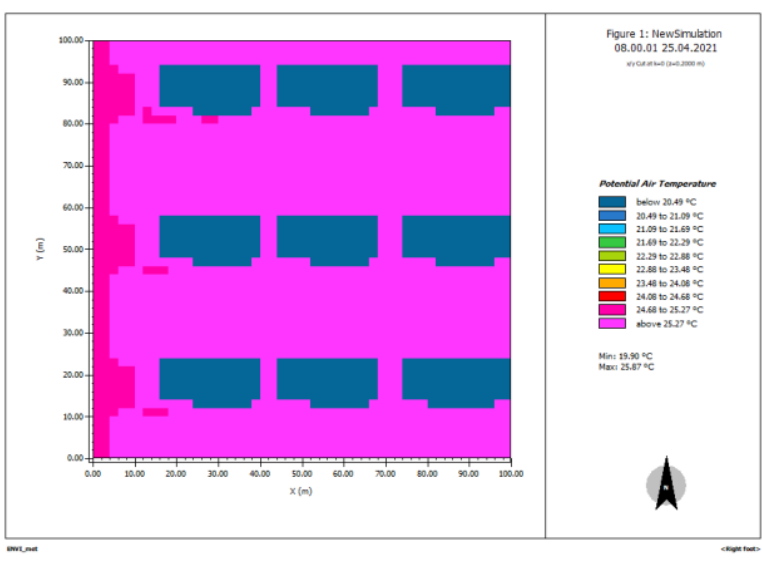

Figure 4: Graph for Model 2(8AM-9AM) 


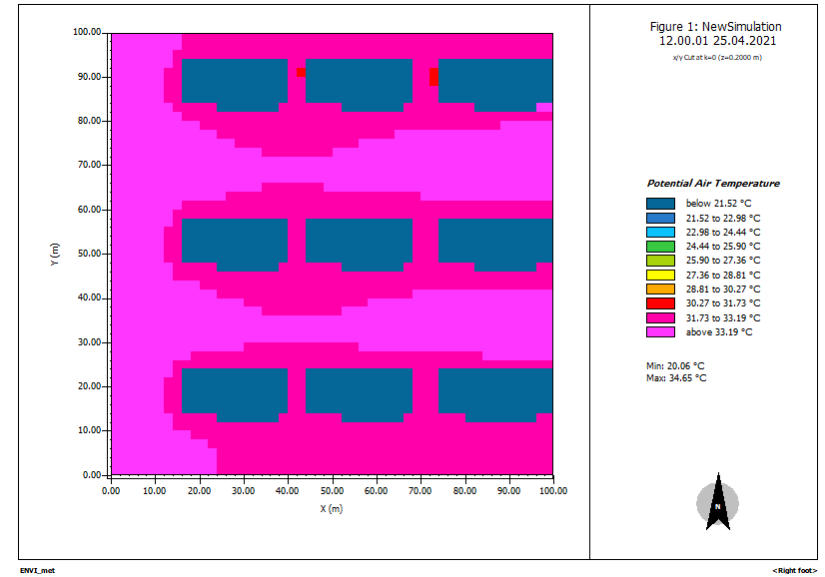

Figure 5: Graph for Model 1 (12PM-1PM)

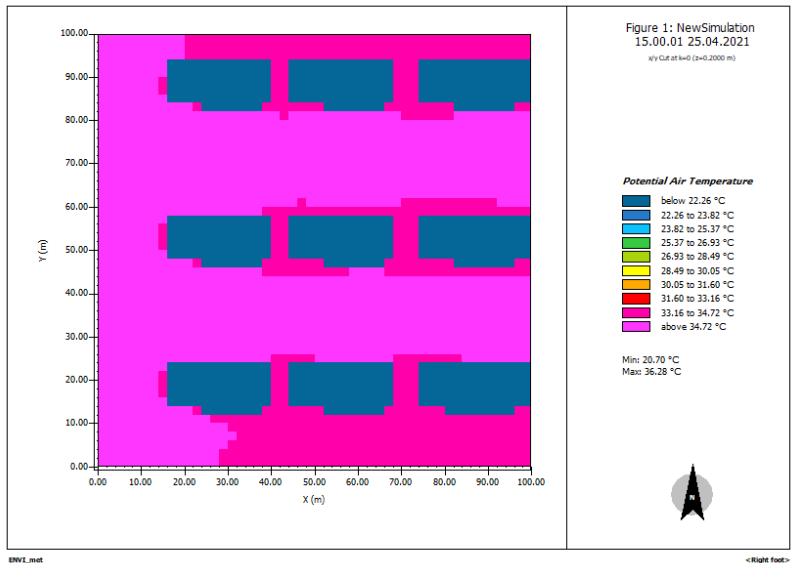

Figure 7: Graph for Model 1 (4PM-5PM)

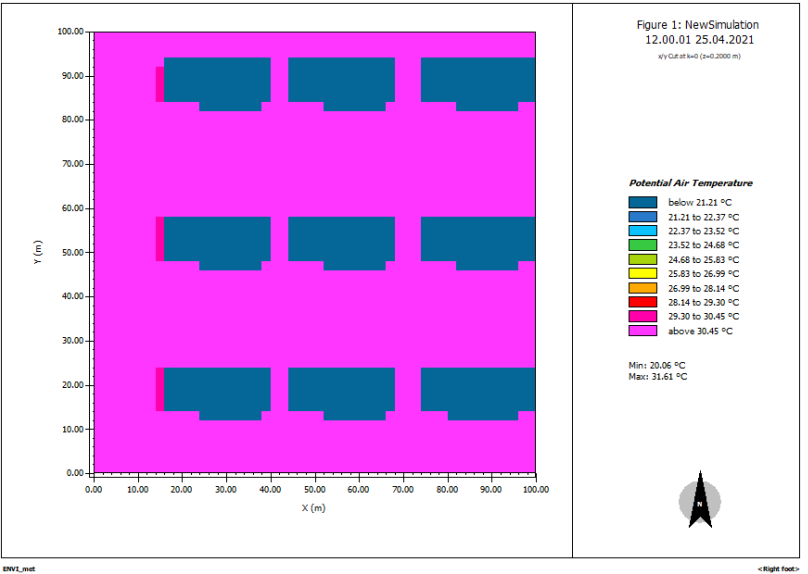

Figure 6: Graph for Model 2(12PM-1PM)

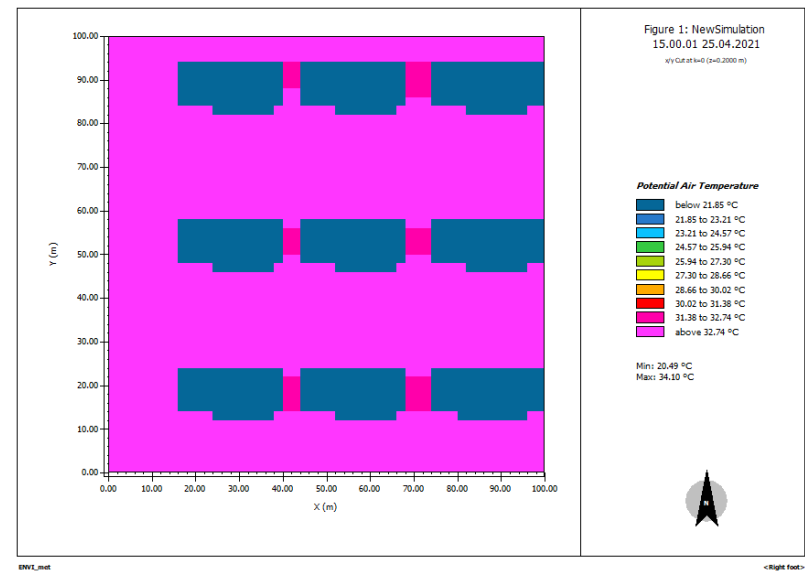

Figure 8: Graph for Model 2 (4PM-5PM)

\subsubsection{Inferences obtained from Potential Air Temperature Graphs}

From the temperature graphs, it was evident that reflective pavements can substantially reduce air temperatures when compared to the dark-colored asphalt pavements. Landscaping elements such as grass used in building exteriors instead of concrete pavements can also help reduce air temperatures at neighborhood level. Living walls and green roofs can be used to reduce air temperature instead of using conventional building materials such as bricks.

\section{CONCLUSION}

The phenomenon of Urban Heat Islands is of major concern in cities, in both developing and developed counties. If not dealt with at the earliest, it can lead to drastic consequences and add more heat stress to the already overpopulated and severely polluted cities. In the recent decades, extensive research has been conducted on Urban Heat Islands to understand their origin and mitigation by architecture and planning. Through effective design strategies such as cool roofs, green roofs, green walls, reflective/permeable pavements and urban forestry the negative impacts of the phenomenon can be minimized. Reduction of temperature in cities will not only help in the mitigation of the Urban Heat Island Effect but also considerably reduce the energy consumption, emission of greenhouse gases and storm water runoff to create healthy and more livable urban environments. 


\section{REFERENCE LIST}

A Synnefa, M. S. (2009). Promotion of Cool Roofs in the EU - The Cool Roofs Project. Lawrence Berkeley National Laboratory, 2nd International Conference on Countermeasures to Urban Heat Islands. California Lawrence Berkeley National Laboratory.

Agency, U. S. (2020, November 13). Using Cool Pavements to Reduce Heat Islands. Retrieved from United States Environmental Protection Agency: https://www.epa.gov/heatislands/using-cool-pavements-reduceheat-islands

Ahmad, S., Matloob, H., Warsi, T. R., \& Khan, M. D. (2011). The evaluation of heat island eAect in various cities in Ganga-Yamuna Doab region using MODIS land surface temperature product. Asian J. Environ. Sci. 6(2), 185-190.

Akbari H, L. R. (1999). Characterizing the Fabric of the Urban Environment: A Case Study of Sacramento, California. California, United States of America: Lawrence Berkeley National Laboratory.

Akbari, H. T. (2011). Using Cool Roofs to Reduce Energy Use, Greenhouse Gas Emissions, and Urban Heat--island Effects: Findings from an India Experiment. California, United States of America : Lawrence Berkeley National Laboratory Report.

Akbari, H., \& Levinson, R. (2009). Global Cooling: Policies to Cool the World and Offset Global Warming from CO2 Using Refl ective Roofs and Pavements. Lawrence Berkeley National Laboratory, 2nd International Conference on Countermeasures to Urban Heat Islands. California, United States.

Alexandri E, J. P. (2008). Temperature decrease in a urban canyon due to green walls and green roofs in diverse climates. Building and Environment 43, 480- 493.

Ambinakudige, S. (2011). Remote sensing of land cover's effect on surface temperatures : a case study of the urban heat island in Bangalore, India. Applied GIS 7(1), 1-12.

Amirtham, L. R. (2016). Urbanization and its impact on Urban Heat Island Intensity in Chennai Metropolitan Area, India. Indian Journal of Science and Technology, 1-8.

Arabi R, S. M. (2015). Mitigating Urban Heat Island Through Green Roofs. Current World Environment: An International Research Journal of Environmental Science.

Ardeshir Mahdavi, K. K. (2016). Methodologies for UHI Analysis. In: Musco F. (eds) Counteracting Urban Heat Island Effects in a Global Climate Change Scenario. Springer, Cham.

Arnfield, A. J. (2003). Two decades of urban climate research: A review of turbulence, exchanges of energy and water, and the urban heat island. International Journal of Climatology 23(1):1 - 26.

Authority, C. E. (2021, March 4). Power Sector at a Glance. Retrieved from Government of India, Ministry of Power: https://powermin.gov.in/en/content/power-sector-glance-all-india

B Bass, S. K. (2002). Mitigating the urban heat island with green roof infrastructure. Toronto: Urban Heat Island Summit: Toronto.

Baby, M., \& Arya, G. (2016). A Study of Urban Heat Island and its mapping. Int. J. Sci. Eng. Res. 4(3), 4547.

Benjamin O.Brattebo, D. B. (2003). Long-term stormwater quantity and quality performance of permeable pavement systems. Water Research, Volume 37, Issue 18, 4369-4376.

Briony A.Nortona, A. M. (2015). Planning for cooler cities: A framework to prioritise green infrastructure to mitigate high temperatures in urban landscapes. Landscpaing and Urban Planning, Volume 134, 127-138.

Cynthia Rosenzweig, W. S. (2006). MITIGATING NEW YORK CITY'S HEAT ISLAND WITH URBAN FORESTRY LIVING ROOFS, AND LIGHT SURFACES. New York: A report to the New York State Energy Research and Development Authority.

D.H Lee, E. L. (2013). An Experimental Study on the surface Temperature Depending on Green Roof Vegetation. Korean Sol. Energy Soc, 91-94.

Department of Economic and Social Affairs, P. D. (2019). World Urbanization Prospects: The 2018 Revision. New York: United Nations. 
Devi, S. S. (2006). Urban heat islands and environmental impact. 6th Symposium on the Urban Environment and Forum on Managing our Physical and Natural Resources.

Eban Zachary Bean, W. F. (2007). Evaluation of Four Permeable Pavement Sites in Eastern North Carolina for Runoff Reduction and Water Quality Impacts. Journal of Irrigation and Drainage Engineering/ Volume 133 Issue 6.

Erica Oberndorfer, J. L. (2007). Green Roofs as Urban Ecosystems: Ecological Structures, Functions, and Services. BioScience, Volume 57, Issue 10, 823-833.

G E.Kyriakodisa, M. (2018). Using reflective pavements to mitigate urban heat island in warm climates Results from a large scale urban mitigation project. Urban Climate Volume 24, 326-339.

Golnoosh Manteghi, T. M. (2020). REVIEW, EVAPORATIVE PAVEMENTS AS AN URBAN HEAT ISLAND (UHI) MITIGATION STRATEGY: A REVIEW. International Transaction Journal of Engineering, Management, \& Applied Sciences \& Technologies, 1-15.

Goswami, A., Mohammad, P., \& Sattar, A. (2016). A temporal study of Urban Heat Island (UHI)-A Evaluation of Ahmedabad city, Gujarat. Conference: International Conference on Climate Change Mitigation and Technologies for Adaptation (IC3MTA-2016)At: Synod College, Shillong, Meghalaya, India.

GreenRoofs. (2007). FORD MOTOR COMPANY'S RIVER ROUGE TRUCK PLANT. Retrieved March 29, 2021, from GreenRoofs.Com: https://www.greenroofs.com/projects/ford-motor-companys-river-rouge-truckplant/

Guzmán Sáenz, F. (2019). Optimized Green Walls: Study of Vertical Green Systems' Performance in an Urban Setting. Delft, Netherlands: Delft University of Technology.

Haselbach, L. (2009). Pervious Concrete and Mitigation of the Urban Heat Island Effect. Washington DC: Proceedings; Transportation Research Board Annual Meeting, Transportation Research Board of the National Academies.

Hashem Akbari, R. L. (2012). Global Cooling: Policies to Cool the World and Offset Global Warming from CO2 Using Reflective Roofs and Pavements. Journal of Heat Island Institute International Vol.7-2, 1-10.

Ibrahim Siti Halipah, N. I. (2018). The Impact of Road Pavement on Urban Heat Island (UHI) Phenomenon. International Journal of Technology 9(8):1597.

Jaekyoung Kim, S. Y. (2020). Temperature Reduction Effects of Rooftop Garden Arrangements: A Case Study of Seoul National University. Sustainability 12, no. 15: 6032.

Jennifer K.Gilbert, J. C. (2006). Stormwater runoff quality and quantity from asphalt, paver, and crushed stone driveways in Connecticut. Water Research, Volume 40, Issue 4, 826-832.

Jun-Pill Kim, M. (2009). LAND-USE PLANNING AND THE URBAN HEAT ISLAND EFFECT. Ohio: Dissertation-THE OHIO STATE UNIVERSITY. Retrieved February 28, 2021

Juri Borbora, A. D. (2014). Summertime Urban Heat Island study for Guwahati City, India. Environmental Science, Sustainable Cities and Society.

K VEENA, K. M. (2020). Urban Heat Island studies: Current status in India and a comparison with the International studies. J. Earth Syst. Sci. 129 85, 1-15 (85).

Maria Kolokotroni *, R. G. (2008). Urban heat island intensity in London: An investigation of the impact of physical characteristics on changes in outdoor air temperature during summer. Sciencedirect, 986-998. Retrieved March 1, 2021

Menglin Jin, R. D.-L. (2005). The Footprint of Urban Areas on Global Climate as Characterized by MODIS. Journal of Climate 18(10), 1551-1565.

Minni Sastry, M. M. ( 2013). Sustainable Urban Development: Minimising Urban Heat Island Effect and Imperviousness Factor. Bangladesh: South Asian Network of Economic Research Institutes.

Mohan, M., Kandya, A., \& Arunachalam, B. (2011). Urban Heat Island Effect over National Capital Region of India: A Study using the Temperature Trends. Journal of Environmental Protection 2(04):465-472.

Munro, K. (2012). Designing Out the Urban Heat Island Effect. Department of Architecture: The University of Strathclyde: MRes Building Design and Management for Sustainability. 
N.H. Wong, S. K. (2006). Environmental study of the impact of greenery in an institutional campus in the tropics. Building and Environment 48(2), 2949-2970.

Pérez, G. \&. (2011). Green vertical systems for buildings as passive systems for energy savings. Applied Energy, Elsevier, vol. 88(12), 4854-4859.

Pompeii, W. C. (2010). ASSESSING URBAN HEAT ISLAND MITIGATION USING GREEN ROOFS: A HARDWARE SCALE MODELING APPROACH. Shippensburg, Pennsylvania: DEPARTMENT OF GEOGRAPHY AND EARTH SCIENCE, SHIPPENSBURG UNIVESITY.

Puneeta Pandey 1, D. K. (2011). A study of urban heat island and its association with particulate matter during winter months over Delhi. Sci Total Environ.

RIZWAN Ahmed Memon, D. Y. (2007). A review on the generation, determination and mitigation of Urban Heat Island. Journal of Environmental Sciences, 120-128 .

Rose, L. H. (2003). Characterizing the Fabric of the Urban Environment: A Case Study of Greater Houston, Texas . California, Berkeley: Lawrence Berkeley National Laboratory.

S Konopacki, H. A. (2002). nergy Savings for Heat Island Reduction Strategies in Chicago and Houston (Including Updates for Baton Rouge, Sacramento, and Salt Lake City). Calfornia, United States of America: Lawrence Berkeley National Laboratory, Berkeley, California.

Sarkovich, M. (2009). SMUD Shade Tree and Cool Roofs Program: Case Study in Mitigating the Urban Heat Island Effects. Lawrence Berkeley National Laboratory, 2nd International Conference on Countermeasures to Urban Heat Islands, California: Lawrence Berkeley National Laboratory.

Sharma, N., \& Pandey, P. (2015). Study of Urban Heat Island in Bathinda City, Punjab. 16th ESRI India User Conference.

Soufi Fallahia, S. A. (2016). The Analysis of the Role of Green Walls in Reduction of Heat Islands in Tehran. Space Ontology International Journal, 5 Issue 1 Winter , 31-44.

T Elmqvist, H. S.-B. (2015). Benefits of restoring ecosystem services in urban areas. Current Opinion in Environmental Sustainability, Volume 14, 101-108.

Thomas, G., M.1, S. S., \& J., Z. E. ((2020)). Urban climate and local climate zone classification in the city of Kochi in India. AIP Conference Proceedings 2287, 020008.

U Mazzali, F. P. (2013). Experimental investigation on the energy performance of Living Walls in a temperate climate. Building and Environment, 64, 57-66.

Wang Y, A. H. (2016). The effects of street tree planting on Urban Heat Island mitigation in Montreal. Sustainable Cities and Society, 27, 122-128.

Watkins, R. P. (2007). Increased Temperature and Intensification of the Urban Heat Island: Implications for Human Comfort and Urban Design. Built Environment, Vol 33 No 1, 86-96.

Yang J, W. Z. (2014.). Unintended consequences: a research synthesis examining the use of reflective pavements to mitigate the urban heat island effect. White Pap., Natl. Cent. Excell. Smart Innov., Arizona State.

Yang Junjing, I. D. (2018). Green and cool roofs' urban heat island mitigation potential in tropical climate. Solar Energy: Volume 173.

Yong Liu, T. L. ( 2018 ). A new structure of permeable pavement for mitigating urban heat island. Sci Total Environ.

YOSHINOBU HARAZONO, S. T. (1990). Effects of Rooftop Vegetation using Artificial Substrates on the Urban Climate and the Thermal Load of Buildings . Energy and Buildings, 15 - 16 (1990/91), 435-442.

Yusuff, A. M., Karumuri, R. k., Beig, G., \& Chate, D. (2017). Seasonal Variation of Urban Heat Island and Its Impact on Air-Quality Using SAFAR Observations at Delhi, India. American Journal of Climate Change 06(02):294-305. 